\title{
Genetically modified food and its impact on the environment
}

\author{
S. Wunderlich \& M. Vecchione \\ Department of Health and Nutrition Sciences, \\ Montclair State University, USA
}

\begin{abstract}
The presence of genetically modified food products within our food system has been a topic of discussion around the world. One source of controversy is whether or not the benefits of genetically modified foods outweigh the potential environmental impact of their production. One important environmental impact of genetically modified (GM) foods is the threat to biodiversity resulting from the genetic transfer from GM crops to native plant species. Another concern is that the increased use of herbicides like Monsanto Roundup ${ }^{\circledR}$ will lead to a new generation of herbicide-resistant weeds that could hamper plant growth. Additionally, since GM crops can be resistant to pests as well, this can lead to pests developing resistance genes at a faster rate than normal. Pollution is another environmental issue, including the issue of increased underwater pollution resulting from GM salmon that can lead to the destruction of aquatic life. Many nations, such as the European Union, United States, and Australia, have policies in place that have allowed the entrance of various GM foods into our food system. However, researchers state that one of the problems involved in addressing the environmental issues surrounding GM foods is that there is no universally accepted definition of what constitutes environmental damage or environmental harm. Regarding GM foods, consumers place their trust the most in university scientists and farmers, followed by government agencies and environmental groups with a moderate trust level, and they place the least amount of trust in food producers and supermarkets. The purpose of this paper is to analyze the policies in different countries and the impact of GM food production on the environment.
\end{abstract}

Keywords: GMO, environment, policy, labelling, food production. 


\section{Introduction}

Genetically Modified Organisms (GMOs) are increasingly becoming an integral part of our food production. According to the US Food and Drug Administration, a genetically modified organism is one that has added characteristics that provide some type of benefit, such as increased growth and yield or improved nutritional value [1]. Foods produced through non-organic methods, or conventional foods, often contain GMOs [2]. Conversely, organic food is produced through methods that preserve ecological balance and biodiversity without the use of synthetic fertilizers, sewage sludge, irradiation, and genetic modification, meaning that $100 \%$ organic products do not contain GMOs [3].

The process of genetic modification began during the $20^{\text {th }}$ century, with one of the most notable experiments starting with wheat and rice. During the 1950s, Norman Borlaug wanted to be able to grow these crops more efficiently while using less fertilizer. The result was a variety of dwarfed wheat and rice plants that were able to absorb more nutrients, leading to increased yield. In the 1970s, the first GM food was introduced to the market; this food was the Flavr Savr tomato [4]. The Flavr Savr tomato was genetically modified to have an increased shelf life. However, the quality of the product did not live up to expectations, and the Flavr Savr tomato was unprofitable and failed to succeed in the market.

After the failure of the Flavr Savr tomato, more GM crops were engineered to increase yield and decrease costs associated with production. One such modification led to Monsanto's creation of Roundup Ready crops. The genetic modification of these crops causes changes to the enzyme that the Roundup herbicide targets in plants. This prevents the crop from being damaged when Roundup is used while weeds are eliminated. Another genetic modification created by Monsanto led to the creation of Bacillus thuringiensis, or Bt crops [4]. These crops incorporate characteristics from a soil bacterium that create chemicals toxic to pests. Because of this, yield of Bt crops is increased because they incur less damage.

Today, a variety of these GM crops, namely corn, soybeans, canola, cotton, and alfalfa sprouts, are incorporated into food products on the market, but the prevalence of these GM foods differs from country to country. Consumer concerns over the safety of GM foods have led to the adoption of various policies regarding GMOs in countries worldwide. This paper seeks to examine how such policies have shaped the marketplace in different countries, the negative impact of GM foods on the environment, and the extent to which GM labeling exists for products in US supermarkets.

\section{GM food production in the US}

As of 2012, the US is the top producing country of GM crops. Over $90 \%$ of farmland utilized for corn, soybeans, and cotton contains GM versions of these crops [5]. In fact, acres of GM corn have increased from about 10\% in 1997 to about $85 \%$ in 2009 [4]. There have been about 11,600 applications received from seed developers to test GM crops since $1987,92 \%$ of which have been approved. 
Most of the approved crops consist of varieties of corn, soybeans, potatoes, and cotton with the majority being insect or herbicide resistant. Farmers have been increasing the amount of GM crops that they are planting, and herbicide resistant and insect resistant corn and cotton crops have led to increased revenue [6].

Currently, about $80 \%$ of foods available in US supermarkets contain GM ingredients. Consumers have expressed some concerns about these foods, as evidenced by the recent GM labeling initiative that was voted down in California [4]. Manufacturers have responded to some of these concerns, and the number of GM-free labeled products available on the market increased by about 3,500 from 2000 to 2004 [6]. However, GM foods are still widely available for purchase.

\subsection{Comparison of GM food production in the US with other countries}

Following the US, Brazil, Argentina, Canada, and India are the next largest producers of GM crops. In 2012, about 170 million hectares of GM crops were planted in twenty-eight different countries [5]. Other nations are beginning to plant GM crops as well. In fact, in 2012, Sudan began planting GM cotton, and in 2011, Cuba began planting GM corn. However, GM crops are not as widely accepted in other countries.

In Europe, consumer opinions of GM foods are very negative. GM products became available in the 1990s, and consumers expressed extreme dissatisfaction, accusing scientists of tampering with nature. Activists fought against GM foods being introduced into the marketplace and considered these products to be 'frankenfoods' [4]. In 2003, parts of Austria, France, Spain, United Kingdom, Greece and Italy professed their intent to be GM-free [7]. Currently, the existence of GM crops in the European Union is extremely minimal, and imports of food from other countries are often rejected because they contain GM ingredients that have not been approved by the EU [8]. While GM production remains banned in some European nations, production is still thriving in the US [4].

\section{Policies and regulations in the US}

At present, there is no ban on GM foods in the US, and these items are readily available in the marketplace [4]. Labeling of GM foods is voluntary as well, meaning that companies manufacturing food products containing GM ingredients do not need to inform consumers of their presence. The US Food and Drug Administration (FDA) supports this voluntary system, citing a lack of proof that GM foods can cause harm, such as negative health effects. Because of this, the FDA believes that labels could mislead people into thinking that these foods are harmful. In addition, the FDA opposes the use of the word "free" with regard to labels for food products claiming to contain no GM items because there is no established threshold for a limit of the amount of GM ingredients allowed in a food for it to be considered GM free [9].

The lack of FDA support has the potential to impact consumer opinions regarding GM foods. A study by Roe and Teisl [10] showed that consumers feel 
that health claims on food products that are certified by the FDA are more credible than products that are not. Besides feeling that FDA certified labels are more believable, consumers do not seem to prefer messages stating that GM foods have possible health effects [11]. Instead, they seem to prefer simple messages stating whether or not a food contains GM ingredients [10].

Concerns from consumers and food safety advocates are being voiced, but labeling remains voluntary. In 2012, California initiated a bill to make GM labeling mandatory within the state. However, large food manufacturing companies, such as Monsanto, led the opposition, and the bill was voted down. Other states like Vermont and Washington are also building support for labeling initiatives, but it is unclear whether big businesses will put a stop to this once more [4].

\subsection{Comparison of policies and regulations in the US with other countries}

Although labeling is voluntary in the US, some countries have developed GM labeling laws in response to concerns about the environmental, health, and economic impact of GM foods. However, these regulations differ from country to country. Australia, the European Union, Japan, South Korea, South Africa, and Indonesia have mandatory labeling policies for GM foods while Canada and Argentina have voluntary policies. The European Union has the most strict regulation policy requiring labeling for products containing more than $0.9 \%$ of GMOs, closely followed by Australia with a threshold of $1 \%$, South Korea at $3 \%$, and Japan, South Africa, and Indonesia with 5\% [12, 13].

When these mandatory labeling policies are put into effect, food companies have the option of either labeling their products or reformulating their products without GM components [13]. A study by Gruère et al. [14] shows that in Europe, food companies chose to reformulate their products rather than label them because they felt that there was a greater purchasing trend toward GM-free foods. Studies by Tsourgiannis et al. [16] and O'Fallon et al. [15] do, in fact, show that consumers in Europe have a strong preference for GM free foods and believe that GM foods are less nutritious and more harmful to the environment. Since many companies chose to sell GM-free foods instead of selling foods with GM ingredients with a label, there are very few labeled foods on the market. Researchers argue that because the mandatory labeling policy in the European Union resulted in a marketplace of almost all GM-free foods, consumers do not actually have a choice in whether or not to choose GM or GM-free foods [14]. In Canada, a country with a voluntary labeling policy, there is a mix of labeled and unlabeled products available, and GM free labels are not as common because consumers know to look for products that are organic if they do not want to consume GM foods [15, 17].

The countries with mandatory policies require labels for products that contain GM components, but some GM-free foods in countries with either mandatory or voluntary policies contain labels stating that they are GM free $[11,14,18]$. Research shows that consumers find labels indicating the presence of GM foods more negative yet more credible than labels indicating that a food is GM-free $[11,14]$. However, consumers who are concerned about the possible health 
impact of GM foods still have a high intent to purchase foods labeled as GMfree [11].

\section{Impact on the environment}

There has been some controversy worldwide about whether or not the benefits of genetically modified foods outweigh the potential environmental impact of their production [19]. Researchers have cited multiple factors of GMO cultivation that can lead to changes in the environment. One important environmental impact of genetically modified foods is the threat to biodiversity resulting from the genetic transfer from GM crops to native plant species. Genes from GM crops can spread to wild types of the same crop, such as a gene from GM maize invading the genetic makeup of non-GM maize. This genetic transfer could cause GM genes to dominate, potentially wiping out the wild variety. Because of this, genetic diversity will greatly decrease, and the desirable traits from wild type crops will no longer be available because these varieties will no longer exist [20, 21].

A related concern to the threat to biodiversity is that GM crops will lead to the development of a monoculture where only one variety of a certain crop is present in large amounts. This is an issue because an insect plague or crop disease can cause vast destruction of the entire crop. Furthermore, planting only one type of crop continually leads to the depletion of soil nutrients and erosion, making the soil unusable for future agricultural use. The development of a monoculture causes a lack of diversity in the availability of foods in the marketplace as well [21].

Another concern is the potential impact of the increased use of pesticides like Roundup. Monsanto's "Roundup ready" GM crops allow for large amounts of herbicides to be sprayed on the plants without causing them any harm [4]. However, researchers believe that this will lead to a new generation of pesticideresistant weeds that could hamper plant growth and grow uncontrollably [21, 22]. According to Food and Water Watch [23], the number of herbicide-resistant weeds reported by US states in 2012 was higher than in previous years. Also, Owen and Zelaya [22] found that the amount of herbicide-resistant soybeans and maize has been steadily increasing, making this issue a real concern. Additionally, since some GM crops are resistant to pests as well, this can lead to pests developing resistance genes at a faster rate than normal. This means that crops would be vulnerable to damage from pests, even after being sprayed with pesticides. The genetic resistance of insects can also lead to changes in the food chain because of the insects' increased population size [22]. Pollution is a concern as well from possible increased use of herbicides and pesticides. In fact, the amount of herbicides utilized for corn, soybeans, and cotton has increased in the US since 2002 [23]. Besides GM plant production leading to a possible increase in pollution, GM salmon cause increased underwater pollution, resulting in the destruction of aquatic life [24]. 


\subsection{Addressing environmental issues}

Many nations, such as the European Union, United States, and Australia, have policies in place that have allowed the entrance of various GM foods into our food system [19, 25]. For example, the European Union utilizes the SAFE FOODS Risk Analysis Framework to analyze the safety and environmental impact of GM foods, but some states argue that this framework does not adequately assess the long-term effects of these foods on the environment [26]. In fact, researchers stated that one of the problems involved in addressing the environmental issues surrounding GM foods is that there is no universally accepted definition of what constitutes environmental damage or environmental harm. Because of this, it is difficult to assess the environmental safety of GM crops $[27,28]$. Furthermore, the long-term environmental impacts of GM crops cannot yet be determined because these issues occur over time. In the case of DDT, people were unaware of the harmful effects for a very long time. It is possible that the same thing could happen with regard to GM foods [29]. When it comes to formulating opinions about GM foods, consumers place their trust the most in university scientists and farmers, followed by government agencies and environmental groups with a moderate trust level, and they place the least amount of trust in food producers and supermarkets [30]. This could mean that if scientists and farmers conduct more studies regarding the negative environmental impacts of GM foods, then consumers may react more negatively towards these products. In turn, more focus might be placed on addressing these environmental issues.

\section{Preliminary findings of GM and GM-free products in selected local supermarkets}

Regarding US supermarkets, our preliminary research shows there seems to be a difference in the approach in how non-GM and organic foods are presented to the customers. High-end supermarkets in the US include Whole Foods and Fairway Market. Moderately priced supermarkets include Trader Joe's and King's. Discount or value supermarkets include ShopRite, Stop \& Shop, and Pathmark. Preliminary research was conducted in a Whole Foods supermarket in West Orange, NJ, Trader Joe's in Paramus, NJ, and ShopRite in Clifton, NJ. A total of three customer service managers, one at each supermarket, were questioned. In addition to speaking with these managers, observations of food products and shelf labeling were conducted at each store to determine the presence of GM and non-GM foods. Based on the 2012 census data, the average per capita income in Clifton, $\mathrm{NJ}$ is $\$ 30,378, \$ 40,098$ in Paramus, NJ, and $\$ 41,278$ in West Orange, NJ [31-33]. Less high-end supermarkets are present in Clifton, NJ, and a mix of high-end, moderately priced, and discount or value supermarkets are present in Paramus, NJ and West Orange, NJ, which coincides with income level.

From the preliminary findings, the Whole Foods in West Orange, NJ carried the most organic and non-GM foods. Every aisle contained some organic or nonGM foods, and to make these items stand out, there was a label below the price 
of the item that stated either "organic" or "non-GMO product certified." A customer service representative stated that the number of organic and non-GMO products sold has increased and that there has been an increase in the number of customers asking whether or not a certain product contains GM ingredients. The customer service representative also indicated that Whole Foods is moving towards carrying only non-GM products over the next few years.

In comparison, at the ShopRite in Clifton, $\mathrm{NJ}$, the customer service manager was not very familiar with the term "GMO" and was not sure if any items carried were non-GM foods. The manager did say that there has been an increase in healthy foods carried, which was reflected by an aisle containing healthy items. However, only about half of the aisle was dedicated to these healthy foods, and they were not GM-free or organic products. Organic items were disbursed throughout other aisles next to their non-organic counterparts, but they were not highlighted in any way. The only part of the store highlighting organic items was a small section of organic produce in the produce section that had a sign hanging over it. The customer service manager said that she has noticed an increase in customers asking about organic foods, but no customer has ever asked about non-GM foods.

At Trader Joe's in Paramus, NJ, the preliminary findings were somewhere in between. Non-GM foods were not visibly highlighted in the store. However, the customer service manager stated that all Trader Joe's brand products are nonGM. Since most of the products sold in the store are Trader Joe's brand, this makes most offerings non-GM. In fact, the customer service manager stated that about $98 \%$ of products carried are non-GM foods. When asked why there were no signs indicating which foods were non-GM products, the customer service manager replied that customers who shop at Trader Joe's already know that Trader Joe's brand products do not contain GMOs, eliminating the need for such labeling. The fact that Trader Joe's brand products do not contain GM ingredients is, in fact, mentioned on the company's website. The customer service manager also said that was an increase in customers asking for more information about which products in the store do not contain GM ingredients.

Based on these findings, it seems that more high-end supermarkets are more concerned with selling non-GM foods than discount or value markets. Nielsen et al. [34] suggest that in high-income areas, consumers can afford to be more discriminating about the food products that they want to purchase and may refuse to buy GM foods no matter how much cheaper they are. Since the Whole Foods and Trader Joe's are located in more affluent areas than ShopRite, a reason for the prevalence of non-GM foods in those two supermarkets may be that consumers can afford to purchase more of these items, even if they are more expensive. King [35] also suggests that there is an expectation that low-income consumers will more readily accept GM foods because their lower price, which could be the reason for the lack of prominence of non-GM foods in ShopRite. Also, the study conducted by King [35] found that about $80 \%$ of the low-income individuals surveyed did not have any knowledge or awareness of GM foods. Clifton, NJ had the lowest per capita income of the three supermarkets surveyed, and the ShopRite in Clifton did not display any information about non-GM 
foods. This could contribute to low awareness because these consumers may not know the nature of the ingredients in the foods that they are purchasing. The King [35] study also found that after participants were provided with information about GM foods, they expressed concerns about the safety of these foods as well as concerns about whether tampering with food is ethical. They liked that GM foods could provide more nutrients and be beneficial to developing countries, but they were still in favor of labeling and of learning more about these foods altogether. Based on this information, it is possible that if labeling were to become more prevalent in all supermarkets, even low-income or value-shopping consumers may think twice about buying GM foods.

\section{Conclusions}

The prevalence of GM foods varies from country to country around the world based on existing policies and legislation. The long-term environmental impacts of GM food production are still not completely known, but research shows that these crops may have negative effects, such as threatening biodiversity and increasing the prevalence of herbicide and pesticide resistant weeds and pests. The US is the leader worldwide in GM food production, and these foods are readily available on supermarket shelves. If GM foods continue to dominate supermarket shelves in the US and consumers continue to buy them, than there may be less pressure for the government to pass GM labeling regulations. Our preliminary research indicates that more non-GM products can be found in higher-end supermarkets, but more research needs to be conducted. Future research can study the reasoning behind the differences in the marketing of nonGM foods in the supermarkets.

\section{References}

[1] U.S. Food and Drug Administration. Questions \& Answers on Food from Genetically Engineered Plants Web Site, Washington, DC, http://www.fda.gov/food/foodscienceresearch/biotechnology/ucm346030. htm

[2] U.S. Food and Drug Administration. Difference Between a Dietary Supplement and a Conventional Food Web Site, Washington, DC, http://www.fda.gov/aboutfda/transparency/basics/ucm194357.htm

[3] U.S. Department of Agriculture. National Organic Program Web Site, Washington, DC, http://www.ams.usda.gov/AMSv1.0/nop

[4] Martin, C., The psychology of GMO. Current Biology, 23(9), pp. R356R359, 2013.

[5] Macmillan Publishers Limited, GM crops: A story in numbers. Nature, 497(7447), pp. 22-23, 2013.

[6] Fernandez-Cornejo, J., Caswell, M., Mitchell, L., Golan, E. \& Kuchler, F., The first decade of genetically engineered crops in the United States, Washington, D.C.: Economic Research Service USDA, 2006.

[7] Choi, E.K., International trade in genetically modified products. International Review of Economics \& Finance, 19(3), pp. 383-391, 2010. 
[8] Davison, J., GM plants: Science, politics and EC regulations. Plant Science, 178(2), pp. 94-98, 2010.

[9] U.S. Food and Drug Administration. (2001). Guidance for Industry: Voluntary Labeling Indicating Whether Foods Have or Have Not Been Developed Using Bioengineering Web Site, Washington, DC, http://www.fda.gov/Food/GuidanceRegulation/GuidanceDocumentsRegul atoryInformation/LabelingNutrition/ucm059098.htm

[10] Roe, B. \& Teisl, M.F., Genetically modified food labeling: The impacts of message and messenger on consumer perceptions of labels and products. Food Policy, 32(1), pp. 49-66, 2007.

[11] Teisl, M.F., Radas, S., \& Roe, B., Struggles in optimal labelling: how different consumers react to various labels for genetically modified foods. International Journal of Consumer Studies, 32(5), pp. 447-456, 2008.

[12] Carter, C.A., International approaches to the labeling of genetically modified foods. University of California Giannini Foundation Update. 6(1), pp. 1-10, 2002.

[13] Vilojen, C.D. \& Marx, G.M., The implications for mandatory GM labeling under the Consumer Protection Act in South Africa. Food Control, 31(2), pp. 387-391, 2013.

[14] Gruère, G.P., Carter, C.A., \& Farzin, Y., What labeling policy for consumer choice? The case of genetically modified food in Canada and Europe. Canadian Journal of Economics, 41(4), pp. 1472-1497, 2008.

[15] O'Fallon, M.J., Gursoy, D., \& Swanger, N., To buy or not to buy: Impact of labeling on purchasing intentions of genetically modified foods. International Journal of Hospitality Management 26(1), pp. 117-130, 2007.

[16] Tsourgiannis, L., Karasavvoglou, A., \& Florou, G., Consumers' attitudes towards GM Free products in a European Region. The case of the Prefecture of Drama-Kavala-Xanthi in Greece. Appetite, 57(2), pp. 448458, 2011.

[17] Gruère, G.P., A preliminary comparison of genetically modified food labelling policy in Canada and France, Food Policy, 31(2), pp. 148-61, 2006.

[18] Crespi, J.M. \& Marette, S., “Does Contain” vs. "Does Not Contain”: Does it matter which GMO label is used?, European Journal of Law and Economics, 16(3), pp. 327-344, 2003.

[19] Cocklin, C., Dibden, J., \& Gibbs, D., Competitiveness versus 'clean and green'? The regulation and governance of GMOs in Australia and the UK, Geoforum, 39(1), pp. 161-173, 2008.

[20] Pandey, P.P., Kumar, B.B., \& Tiwari, D.K., Environmental Considerations Concerning the Release of Genetically Modified Organisms, Proenvironment Promediu, 3(6), pp. 381-384, 2010.

[21] van den Bergh, J.C. \& Holley, J.M., An environmental-economic assessment of genetic modification of agricultural crops, Futures, 34(910), pp. 807-822, 2002. 
[22] Owen, M.D.K., \& Zelaya, I.A., Herbicide-resistant crops and weed resistance to herbicides, Pest Management Science, 61(3), pp. 301-311, 2005.

[23] Food and Water Watch. Superweeds Web Site, Washington, DC, http://documents.foodandwaterwatch.org/doc/Superweeds.pdf

[24] Le Curieux-Belfond, O., Vandelac, L., Caron, J., \& Séralini, G.E., Factors to consider before production and commercialization of aquatic genetically modified organisms: the case of transgenic salmon, Environmental Science \& Policy, 12(2), pp. 170-189, 2009.

[25] König, A.A., Cockburn, A.A., \& Crevel, R.R., Assessment of the safety of foods derived from genetically modified (GM) crops, Food \& Chemical Toxicology, 42(7), pp. 1047-1088, 2004.

[26] Kuiper, H.A., \& Davies, H.V., The SAFE FOODS Risk analysis framework suitable for GMOs? A case study, Food Control, 21(12), pp. 1662-1676, 2010.

[27] Bartz, R., Heink, U., \& Kowarik, I., Proposed definition of environmental damage illustrated by the cases of genetically modified crops and invasive species, Conservation Biology, 24(3), pp. 675-681, 2010.

[28] Sanvido, O., Romeis, J., Gathmann, A., Gielkens, M., Raybould, A., \& Bigler, F., Evaluating environmental risks of genetically modified crops: ecological harm criteria for regulatory decision-making, Environmental Science \& Policy, 15(1), pp. 82-91, 2012.

[29] Schermer, M., \& Hoppichler, J ., GMO and sustainable development in less favoured regions - the need for alternative paths of development, Journal of Cleaner Production, 12(5), pp. 479-489, 2004.

[30] Lang, J.T., Elements of public trust in the American food system: Experts, organizations, and genetically modified food. Food Policy, 41, pp. 145$154,2013$.

[31] U.S. Department of Commerce, Clifton, NJ State and County QuickFacts Web Site, Washington, DC, http://quickfacts.census.gov/qfd/states/34 /3413690.html

[32] U.S. Department of Commerce, Paramus, NJ State and County QuickFacts Web Site, Washington, DC, http://quickfacts.census.gov/qfd/states/34 /3455950.html

[33] U.S. Department of Commerce, West Orange, NJ American FactFinder Web Site, Washington, DC, http://factfinder2.census.gov/faces/ tableservices/jsf/pages/productview.xhtml?pid=ACS_12_3YR_DP03\&pro dType $=$ table

[34] Nielsen, C., Thierfelder, K., \& Robinson, S., Consumer preferences and trade in genetically modified foods, Journal of Policy Modeling, 25(8), pp. 777-794, 2003.

[35] King, N.J., Low-income consumers, though less aware of genetically modified foods, are concerned and want labels, California Agriculture, 57(3), pp. 81-85, 2003. 